\title{
Axiological Systems Theory: a general model of society.
}

\author{
Francisco Parra-Luna
}

\author{
Universidad Complutense \\ Facultad de Politicas \\ Somosaguas, 28023 Madrid \\ e-mail: parraluna@cps.ucm.es, vivianpa2000@yahoo.es
}

\begin{abstract}
Societal problems can be defined as some kind of axiological disequilibrium since values can be considered to be the raw material, which founds social phenomena. If "values" is the "degree of usefulness or suitability of things to satisfy necessities", or to use more sociological terms, If "value is an element of a shared symbolic system which serves as the criterion for choosing between alternatives for orientation", then, it can be extrapolated that everything, or almost everything in the field of human relations, can be considered as an enormous and complex framework of necessities and interests which can only be satisfied through the achievement of values. Thus the worker tends to aim for an adequate standard of living, security and personal satisfaction; the student looks for knowledge and preparation for the future; the sportsman for health and perhaps glory and prestige; and so on. This can also be seen in institutions: Education stresses knowledge; Economy the material side of living; the Armed Forces, security and order;
\end{abstract}

etc. The reason for existence of institutions, the aim of all human association, from the two lovers or two friends, to the United Nations Organization, passing through the family, the firm, or the State, is solely due to the need for carrying out and attaining values which will satisfy original or derived necessities. A central hypothesis in this paper is to support that any systemic theory of society could not avoid to deal with values as the basic raw material for defining and measuring its performance and for achieving the best possible solution of societal problems.

Keywords: Axiological, Values, Needs, Transformation, Regulation, Reference Pattern of Values, System of Values.

\section{Introduction}

Modelling is one of the best methodological instruments to represent heuristically complex societies. We of course must try to model society in a way that is both so simple that it will afford a clear view of society and so thorough that it conceals nothing essential. Reaching such a balance will be no easy task and will certainly entail several attempts. Here goes a first such try. I am going to refer to a model on which I have been working for several years now (Parra-Luna 1974, 1977, 1983) although the version discussed here is slightly modified. The starting point for this model, for which I am indebted to $D$. Easton (1965) and K. W. Deutsch (1974), is the cybernetic-transformational approach that converts inputs into outputs via, as explained above, a transforming body usually called the "Black Box". To illustrate the model I will take as complex a society as possible, the current nation state, although I will also refer to other smaller social entities such as local governments, companies, universities, groups or families. The model is intended to be applicable to them all. I realise that adopting the nation state as an example will make the reader even more wary, if possible, of the operational possibilities of this new systems theory that I am attempting to introduce. Nonetheless I will use this macrosociological dimension for three reasons: 1) because the model intends merely to be a sketch or outline for a wholly operative model and, as such, the relevance of any specific shortcomings that may arise in the description is limited; 2) because even if the model is only partially valid in relation to the nation state, the implication would be that it would 
automatically cover all other smaller systems (institutions, organisations, groups, etc.); and 3) because the nation state, which represents an integrated macrosociological system, is meaningful for the set of endvalues that make up what I will call the "Reference Pattern of Values". For example, the nation state illustrates an important consequence of this theoretical approach, i.e. the axiological differentiation between ideologies and political regimes revealing their inner-most structure in relation to the interests, needs and motivations of their respective people or the ruling class that represents them, while at the same time shedding light on the explanation for much of the behaviour of the institutions, organisations, companies and groups that make it up. (Buchanan 1998 and 2000; Hall B.P., 1994; Hall Martin-Lewis, W. 1999).

\section{Society: A General Model}

The first thing that must be explained about this model is what is meant by inputs and outputs, and the distinction between the two must be made very clear for the sake of understanding. By outputs we mean anything that, with respect to society, is simultaneously: 1) defined as "good" by a representative sample of experts; 2) wanted or desired by the people (because it tends to satisfy their needs); 3) obtainable onerously or through organised political action within the system.

Two conceptual levels of inputs may be distinguished: a) Theoretical level, where inputs are considered to be the system's potential to produce outputs. This would mean including in a single expression $(X)$ the structural factors used (SF), the level of people's needs or motivation (N), the level of memory (M) or record of the recent past, and finally the influence of the environment $(\varepsilon)$; implicitly expressed: $X=f(S F, N$, $M, \varepsilon)$. And b) operational level, where to sidestep the difficulties that the quantification of SF, N, M and $\varepsilon$ entails, inputs are taken to be the system's overall budgeted expense plan expressed in monetary units, which is the approach usually taken in all kinds of institutions, companies and organisations. Hence, on this simplified level, $\mathrm{X}$ would represent the budgeted expense plan.

In short, what enters into the transforming body is either the potential system production or the actual consumption in monetary units; what comes out are the goods and services consumed or made available to the society at large. Inputs are, then, the useable resources, or resources used; outputs are the ends achieved.

\begin{tabular}{|c|c|c|}
\hline INPUTS & TRANSFORMATION & OUTPUTS \\
\hline $\begin{array}{l}\text { All the factors that condition } \\
\text { outputs, including the output } \\
\text { themselves through feed back. }\end{array}$ & $\begin{array}{l}\text { Organization } \\
\text { Structures } \\
\text { Processes } \\
\text { The operational intelligence of the } \\
\text { system. }\end{array}$ & $\begin{array}{l}\text { What satisfy the needs interests } \\
\text { and expectations of people. } \\
\text { What is good according to the } \\
\text { experts. } \\
\text { What is obtainable onerously }\end{array}$ \\
\hline
\end{tabular}

Table 1: Distinction between "Inputs" and "Outputs" of social systems

Table 1 intends to make this distinction very clear and at the same time enunciate the fundamental principle of transformation adopted in our model: not everything that comes out goes in, and not everything that goes in comes out. In this latter case I will try, in due course, to justify the possible "reducing" role of the Black Box or transforming sub-system.

The operational model shown in Fig. 1 (p.3), built on this basic model, is an attempt to explain the most relevant dimensions of the social system as a continuing process of transforming relationships. 


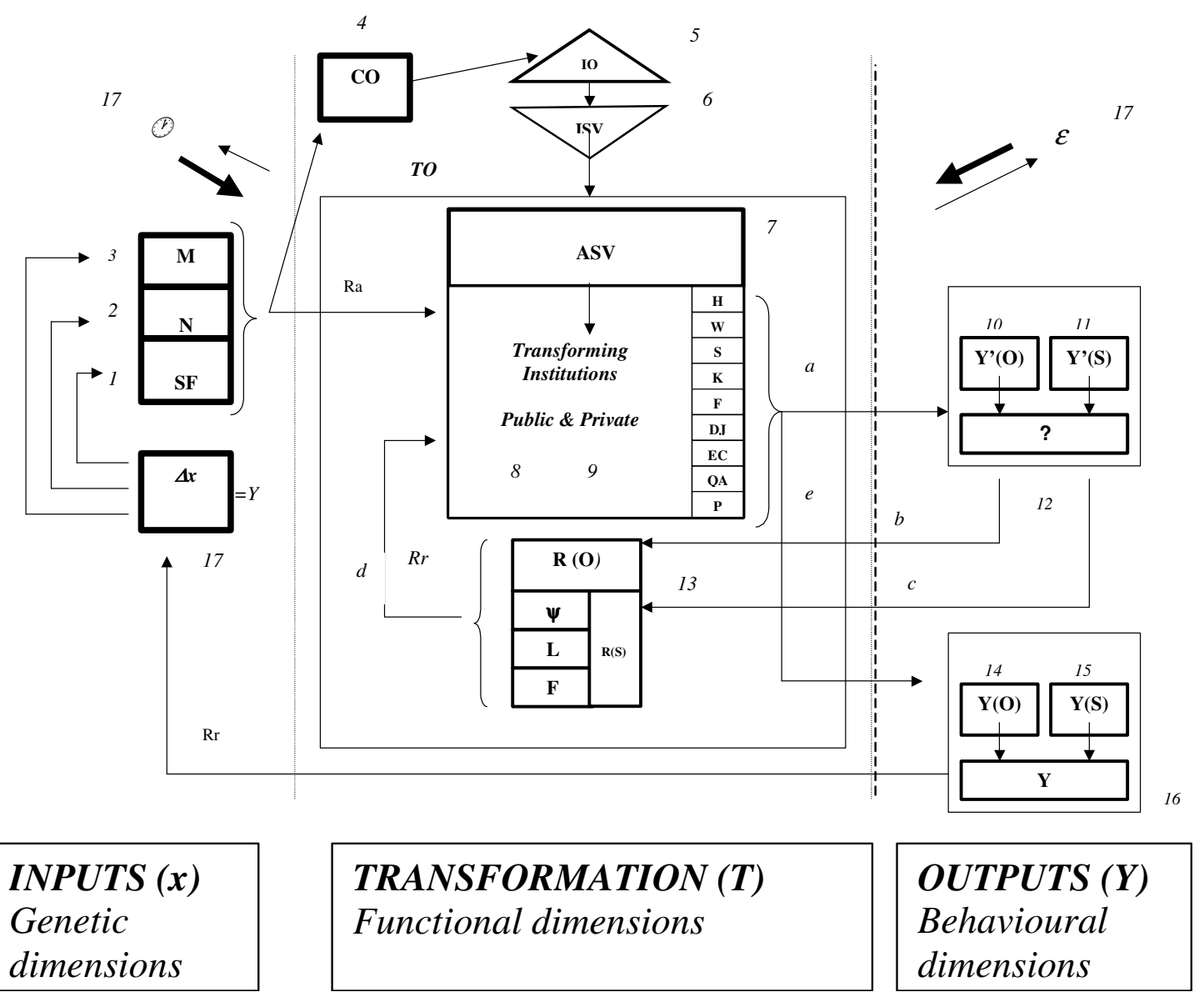

Figure 1. A general simplified model for social systems

Let us then see, first of all, what specific inputs reach the transforming sub-system in any social system. initially, there are three kinds of inputs: the first consists of a series of structural factors, quite numerous and complex which, in the case in point, i.e. the nation state would be ecological, geographic, geological, cultural, religious, political, demographic, etc. factors. For example: Spain is a country with a series of natural resources such as an area of $504000 \mathrm{~km}^{2}$, nearly $7.500 \mathrm{~km}$ of coastline, with France, Portugal or even Morocco as neighbours, 40 million inhabitants with clearly defined physical and biological traits, a certain wealth in fishery resources, etc. All these are factors involving structure which are difficult to change, which remain more or less constant over time and for this reason may be referred to as "Structural Factors". They are represented as a pooled variable abbreviated as "FE" in Fig. 1 (p.3) and constitute what I call the system's "Level of Potential". The use of these resources as inputs is likewise evident in smaller social systems. For example, in the classroom as a system, inputs would be the professor's salary, the use of certain material resources (buildings, furnishings, etc.) and the time the students devote to class work. We know that with all that the outputs or system of values produced by the classroom (stressing, of course, the value "Knowledge") must be maximised, as we shall see.

Going back to the example of the nation state, as a result of the structural factors mentioned above, both individual and collective needs arise. Sight should not be lost of the fact that the structural factors include the population factor which in the case of Spain consists of nearly 40 million inhabitants with a series of needs to be met. One way of seeing that needs are in fact also "coming in" to the system would be to consider that they represent the motivation or essential stimulus for system operation. In order to register these needs we will in due course refer to the underlying values that correspond to them, and this will in turn call for the use of a general pattern of end-values which theoretically form an exhaustive and 
closed axiological whole. Some of the values that satisfy these needs are security (law and order), justice, freedom, health, environmental conservation, etc., in as much as they are the answer to specific needs felt by the 40 million inhabitants that make up the Spanish social system. They are represented as a pooled variable abbreviated by the letter "N" in Fig. 1 (p.3) and constitute what we will call the system's "Level of Motivation".

The third category of inputs consists of what may be called system "Memory", since any organised society has a kind of historical "archive" (written or otherwise), which allows it to remember its specific history more or less forever. Using Spain as an example once again, the historical, cultural and linguistic ties with Latin America, its past Arabic influence, or even its recent civil war, may foster certain kinds of conduct or cause traumas and condition behaviour both in the population at large and in the ruling elite that may ultimately have a substantial impact on Spanish politics. It is, then, assumed that all societies have a memory that influences them and "comes in" to the "Black Box" to, together with the structural factors and needs, be transformed into outputs. This memory is represented by a pooled variable abbreviated as "M" in Fig. 1 (p.3).

Finally, the possible influence of the environment represented by its level of outputs or fulfilments is likewise an input, although of an external nature. In the present example, the environment may consist of the other European Union member countries, computed to be the average of the national output levels in such countries and symbolised as $(\varepsilon)$.

But social systems differ from mechanical or biological systems in that the individuals making up the society are neither in agreement about the ends to be achieved to meet their needs (or the relative weight that each should carry), nor about the resources to use or the way to organise the factors mentioned above in order to transform them into end-values. This is a basic disagreement that affects the core of society; a nearly anthropological disagreement that is fundamental and specific to socio-cultural systems and one which generates a constant structural conflict in all societies. There is, then, an inescapable necessity to overcome such discord, a fundamental dimension of the system recognised not only by the Marxist tendency, but by previous traditional thinkers such as Polybius, Hobbes and others. The solution to this conflict entails an institutionalised struggle, more or less latent, more or less recognised, that is structurally present in all social systems. This struggle may be physical or simply dialectic, involve tanks or ballot boxes, an old-fashioned spanking or modern dialogue with one's children, but in any case it implies some sort of struggle as a way of solving the problem posed by axiological disagreement, which is practically inevitable. Such disagreement is represented by a pooled variable abbreviated as "CO" (Conflict) or "Level of Conflictiveness" in Fig. 1 (p.3). Such a phenomenon is likewise present in other kinds of organisations: A company when there is a struggle for membership on the board of directors or in any other kind of organised group for a seat on the steering or executive committee.

Such institutionalised conflict is usually more a real struggle than a friendly discussion with equitable distribution of capacity to define what the system should produce; in other words, the struggle normally generates "winners" and "losers" and as a result a hierarchy defined by the total power (economic, connections, positioning, physical, etc.) of individuals and groups, which hierarchical structure is usually more or less unchanging over time. We will see below how in this process involving struggle and resulting hierarchy it is the elite classes (economic, intellectual, military, labour, etc.) more than the population at large that play the predominant role. For this reason the pyramid that the "Inspiring Organ" (IO) represents in the system in Fig. 1 (p.3) is composed exclusively of the formal (explicit) and informal (implicit) elite that inspire society's workings. This body is represented by a pooled variable "IO" and denotes its "Level of Hierarchy".

The elite shown on the upper part of this pyramid are the ones that decide what, when and how the system should produce. These ruling elites are the ones that determine the axiological profile that society 
should adopt and which in our figure is represented by the ISV or "Idealised System of Values" pyramid. According to the definition of this profile, the ruling or prevailing elite may consider, for example, that freedom is more important than justice (justice meant here in the sense of social justice), while in other axiological systems the contrary may be true. These are ideological options that either stand for more or less concealed personal interests, or derive from a deep axiological inclination. In any case the winners impose or try to impose certain principles for operation of the system which are summarised in what I have called the "Idealised System of Values": Idealised, I repeat, not necessarily in the interests of the entire population, but in those of the ruling elite who are the ones with the power to define such a system and implement it in terms, moreover, of their "specific interpretation" of the people's needs. It is represented by a pooled variable abbreviated as "ISV" in Fig. 1 (p.3) and denotes the "Level of Ambition of the Ruling Elite".

This "Idealised System of Values" will drive the operational and transforming machinery of the system or the transforming sub-system, which is subdivided, in turn, into two parts. The first of these is represented by the system of values that governments programme, usually as a specific plan of action that consists of adjusting the scheme (or better, schemes) of values idealised by the ruling elite (ISV), in the light of environmental contributions $(\varepsilon)$ and the capacity of the structural factors (SF) of the system itself. This operation is represented by a pooled aggregate abbreviated "ASV" (Adjusted System of Values) and constitutes the "Level of Governmental Ambition". This ASV arises (or should arise) as the result of performing certain technical operations to optimise outputs in terms of ISV, N, SF, M and even " $\varepsilon "$. In the mathematical sense, this optimisation operation is technically very complicated in complex systems, and for this reason is rarely performed. This would, nonetheless, represent the "Optimum Level of Possibilities" of the system. The second, unspecified part of the transforming sub-system is of a material and organisational nature and comprises first of all the traditional powers: Representative, legislative, executive and administrative. Moreover, it covers all public and private, institutional or individual entities, from huge ministerial bureaucracy to even the most insignificant of professional activities, which are what in practice implement (implicitly, through monetary, tax, social, labour, etc. policies) the directives of the inspiring body, transforming the incoming "raw materials" (structural factors, needs, memory, environment) into "finished products" (values) to be "consumed" by society as a whole. This residual part of the Black Box is represented by a pooled variable abbreviated "TO" in Fig. 1 (p.3) and called "Transforming Body". In general, "TO" is the sub-system that comprises the process "Communication-Perception-Memorisation-Decision-Action", which are in turn the main prime materials for the transformation operation in as much as they are mere means or tools to reach certain levels of endvalues. The system begins to produce the goods and services expected of it, the outputs $(Y)$ of the system, through this complex transforming process to meet the needs of the people. Two distinctions should be made, however, with respect to outputs: First, a difference should be drawn between objective and subjective outputs. The so-called "objective" outputs are verifiable with validated empirical data; for example, in the case of the nation state, kilometres of expressways or highways built, percentage of young adults that finish their schooling, degree of improvement in redistribution of income, enjoyment of freedom, etc., and for which there are, or should be, routine and reliable statistical data. Subjective outputs, on the other hand, are those where information about their existence depends on what people perceive or think about the system's objective outputs. It may well be that what people perceive as system outputs are not actually put out by the system at all, there being then a gap or kind of perceptive "discord", which may be positive or negative depending on whether the outputs are perceived to be better or worse than they objectively are. Strikes are a good example of discordant perception (justified or otherwise) with respect to the worth or suitability of objective outputs. Total system performance $(Y)$ must then be the integrated sum of objective $Y(0)$ and subjective $Y(s)$ outputs. Second observation: theoretically there are two kinds of outputs being produced at two different times: Before (dimensions 10 and 11 in Fig. 1 (p.3)) and after (dimensions 14 and 15) regulation (No. 13). The system produces a primary group of outputs, both objective $Y^{\prime}(O)$ and subjective $Y^{\prime}(S)$, the integration of which is equal to " $\theta$ ". But when these outputs 
are controlled, as we shall see below, and possibly modified by the regulating body $\mathrm{R}$, they are expressed as $Y(O)$ and $Y(S)$ respectively, and their integration is equal to "Y". These are the final and definitive outputs once cybernetic control has been performed. How does such control take place?

The regulation $(R)$ mechanism is explained as follows: in principle, whatever is put out, both objective and subjective, should automatically and unfailingly re-enter the system as new inputs. This sets off the following phenomena:

1. The primary objective outputs produced do not usually coincide exactly with the system of values programmed and optimised by the government or managing bodies (ASV) and even less with the ruling elite's "Idealised System of Values" (ISV). In view thereof, and given that such elite try to maintain the initial ideological scheme that best suits their interests or coincides with their own ideologies, they institutionalise the so-called "Regulating Body" (R) whose primary purpose is to modify objective outputs to adjust them as closely as possible to such initial schemes. Such action is performed through what in Figure 1 (p.3) is referred to as $R(O)$, giving rise to the second group of objective outputs $\mathrm{Y}(\mathrm{O})$ or "final objective performance". The social security systems existing in the modern world usually constitute a foremost example of objective regulation. That is to say, since society is unable to prevent disease and accidents, it must make provision for medical and hospital care; since it cannot eliminate crime, it establishes a police and penitentiary system; or since it is unable to provide jobs for all those who want one, it must institutionalise economic compensation for the unemployed.

2. Even if there were no significant difference between programmed and actual outputs, it often happens that the population at large is not satisfied with what the system does. Since such dissatisfaction enters the system as feedback, this could cause a series of disturbances or difficulties that could be harmful to the axiology of the system inspired by the elite classes. What do the ruling elite usually do to avoid this "danger"? What they do and have been doing since the beginning of time, regardless of ideology or form of government, is to exercise a kind of psychocybernetic control through which they either modify the perception of the population at large, or they mitigate the impact of the disturbance produced. The use of primitive versions of political "servomechanisms" or "thermostats" (propaganda, manipulation, threat, etc.) before the servo theory appeared, is as old as humanity. Therefore, the Regulation (R) in Fig. 1 (p.3) should also register the subjective reaction of the system's population and on this basis send a communication intended to modify either the actual outputs or the people's perception of such outputs. The second function of the regulating body consists, then, of discovering when outputs are not accepted by the population; that is when the psycho-regulating mechanism is set off, whereby the impact of any feedback on the existing balance of power and therefore the axiological scheme assumed by the ruling elite is kept to a minimum; this action is performed through $\mathrm{R}(\mathrm{S})$. This second regulating function usually establishes, in turn, three kinds of control: the first is psychological, consisting of messages conveyed by the ruling elite via all possible media (direct and indirect) systematically devoted to singing the praises of their successful management and supporting (even clearly contradicting actual facts) that what is being done is the best that can be done, that any other option would be less favourable for society as a whole and therefore that any other elite or group that might come into power would do a worse job than they. This pattern of psychological control is applicable to a greater or lesser extent to any social or political system. Although in the most extreme version it entails "brainwashing" the population, it is still perhaps the least harmful way of exercising subjective control. Governmental political propaganda, stressing its own success; "doctored" annual company reports; or a father's long-winded speech in reply to what he feels are his sons' or daughters' excessive demands, all of this, justified or not, are simply examples of this kind of psychological control intended to uphold the hierarchical, family or axiological status quo, which the elite 
classes consider to be beneficial, even though the social situation does not necessarily favour a majority of the people.

But there are individuals or groups within the system who are aware, critical or intelligent enough to understand the nature of this kind of control and questioning the reliability of the messages and thereby endanger the effectiveness of such psycho-regulation. Naturally, the ruling elite makes provision for the minorities, which for one reason or another cannot be controlled psychologically; this sets off a second kind of control mechanism which we will refer to as legal control. Such control consists of making laws through the corresponding legislative machinery to implicitly issue the following message, from a position of legal power: "You have a right not to believe what we say, but there is a law that says this or that, and if you do not obey that law you will have to face the consequences (illegality, risk of fine, imprisonment, etc.)," all of which usually works. For example, it is legal to support the doctrine that the means of production should be state-owned, but any practical action in this regard would contradict legislation providing that private ownership of such means is a natural, inalienable or sacred right. Or it may be thought that is it unfair, to use the Spanish state by way of illustration, that Prince Felipe of Spain is heir to the throne instead of his elder sister Elena. But such sexist discrimination, hardly justifiable in today's world, is to be found in the Spanish constitution itself. Whoever rises firmly against these principles must be prepared to accept the (implicit or explicit) consequences of such action.

And yet despite this second kind of control part of the population may still scorn the risk of illegality and be prepared to assume the consequences. Logically, the dominant elite are also aware that there is a minority of individuals or groups who are bold enough to break the law; the executive power then implements a third kind of control that may be called physical or material whereby the recalcitrant rebels are marginalized, made to pay fines, imprisoned, tortured and, if necessary, killed, all quite legally, of course. Parental punishment, dismissal of workers or expulsion of a partner or member, are mere extensions of this kind of control.

In short, the system includes a regulating body with important duties, which I will represent operationally as follows: total regulation is "R"; regulation of objective outputs is "R(O)"; and regulation of subjective outputs is "R(S)"; this latter term can be subdivided into three variables, still pooled, represented by: $\Psi$ for psychological control; "L" for legal control; and " $F$ " for physical control. The effect of "R" on the primary outputs $Y^{\prime}(O)$ and $Y^{\prime}(S)$, the integration of which is represented by " $\theta$ ", leads to the secondary or final outputs $Y(O)$ and $Y(S)$, the integration of which is represented by "Y". These total outputs, at least partially "purified", automatically feed back into the system as new inputs $(\Delta x)$ (body number 16) Fig. 1 (p.3) which are thus assumed to cause the least possible impact on the existing balance of powers. This would explain the densely homeostatic or conservative tendencies of all kinds of pyramidal social systems.

The direction of the arrows in Fig. 1 (p.3) illustrates society's most representative process, a neverending and contingent (vicious / virtuous) circle. Society turns over and over on its initial structural factors, modifying them as well as the other initial conditions via, inter alia, the outputs produced by the operation of the system itself. 
Formally speaking and pursuant to the transformation principle, the outputs produced during period 0-1 depend upon the inputs "X" and the transformation operation "T" in such period; i.e.,

$$
Y_{01}=f\left(X_{01}, T_{01}\right)
$$

and due to feedback, the inputs in the following period "2" depend, in addition to another series of factors represented by $I_{12}$, upon $Y_{01}$ or the outputs in period, "0,1" immediately preceding, where the subscripts "0", "1" and "2" denote the beginning and end of each period studied. Hence

$$
\begin{aligned}
& Y_{01}=f\left(T_{01}, X_{01}\right) \\
& X_{12}=f\left(Y_{01}, I_{12}\right) \\
& Y_{12}=f\left(T_{12}, X_{12}\right)
\end{aligned}
$$

the full cycle being, then, a mere continuation of the above functions.

The model shown in Fig. 1 (p.3) represents both a process and a structure: a process because it attempts to represent the flows as they appear in real life which - a look around suffices to confirm - is a series of events that can only be recorded as a motion picture, not as a photograph. But it also represents a structure because the dimensions and processes indicated in the model are repeated time and again, for better or for worse, with scant prospect of change. In other words, it is difficult to conceive of a society that is not, ontologically speaking, an input / output transformation system, encompassed by an environment that influences it and is in turn influenced by it, and consisting of structural factors, needs, memory, control bodies, etc. It is, then, a process in as much as it is a living, adaptive and relatively changeable entity; and it is a structure in as much as it remains essentially unchanged over time and is applicable to any existing social system, ranging from mere couples to large supranational organisations.

At this point, it is necessary to emphasize that the comparison between " $\Pi$ ", "N", "ISV", "Y(O)" and "Y(S)" would show the obvious similarity between this axiological analysis and some critical analysis like the one derived from the Critical Systems Thinking or approaches (Flood and Jackson 1991; Ulrich 1991).

\section{How Much the System Change?}

According to this description, where the final result $(Y=\Delta X)$ appears to be perfectly regulated and controlled by the ruling elite, it may be concluded that the possibility of change is minimal. Two observations come immediately to mind in this regard: First, that any social system has a series of servomechanisms designed to minimise change, a property known as system homeostasis. History shows that, except for a few historical revolutions (the English, American, French, Russian, Chinese, Iranian, and other lesser revolutions), systems resist drastic and truly significant change. Even in these cases it is questionable whether or not such revolutionary change really affected the population at large in terms of values "consumed", since the changes in institutions on the political, legal or even the sociological level should not be mistaken for real change in levels of health, security (law and order), material wealth, etc., which are the ones that have a true impact on the people. In other words, any analysis of change must consider the concept in the light of the model in Fig. 1 (p.3) in order to determine whether change has come about in the outputs (behavioural dimensions) or on what I have called the "Genetic" or "Transforming" level. These latter may be of great explanatory importance without entailing real change in the satisfaction of the needs of the population at large, which is what should be considered to be real change from the sociological standpoint. Whether a government has 10 ministries or 20 , whether a state comprises one or two legislative houses, or is governed by a constitution that is new or old, means nothing if this does not affect the welfare of the people. The slight attention that Functionalism pays to aspects of change is due essentially to its abuse of this interpretation, drawing analogies, besides, between social and biological systems in respect of the tendency to reach equilibrium; but it is not at all mistaken in 
stressing the inevitably conservative nature of all social systems. However, the fact that such systems are ontologically conservative or follow an irresistible tendency to be so, by no means implies (contrary to erroneous interpretations sometimes put forward in this regard) that the theory that describes such situation is equally conservative.

But despite the above controls and the ruling classes' need to maintain the status quo (essentially with respect to the hierarchical structure of its "Inspiring Organ" (IO), there is no question that there is a whole series of factors that prompt change in the system in one way or another. Hence, for instance, structural factors may change (e.g. the discovery of new minerals, a ban on fishing in traditional fishing banks, natural disasters, etc.). The people's needs also change because systems of values change and evolve over time; historic memory changes due to the accumulation of significant events or the appearance of new interpretations of history; the processes whereby disagreements and conflicts are solved and the system hierarchy established change; the nature of environmental action changes, and with it the enormous influence it has on the system; the above example of the political change in Spain in 1976 is a clear illustration of changes taking place under the influence of the environment and how psychological, legal and physical controls may, after all, be ineffective. In this regard events in Spain after November, 1975, deserve some comment. When General Franco pronounced his famous statement to the effect that Spain's future after his death was "all set, and well set" he did not or would not perceive that the Spanish political system (formal dictatorship) was already "upset", that the socio-cultural bases had changed and that this process had begun with the First Development Plan subsequent to the stabilisation process of 1960 that had prompted emigration, tourism, etc. Rapid development in the sixties had an impact on a series of cultural traits such as more and better schooling, contact with foreign tourists, the secularisation process, etc. A series of occult cultural transformations took place whereby the system, despite the regime's typical psychological, legal and physical control, underwent change which the ruling elite seemed to be either unaware of or unable to counter. Moreover, the ideological clash among the elite themselves was causing profound change in the structure of the inspiring body through what might be called "internal axiological discord" or a power struggle among the elite, even without elections, in an attempt to influence legislative and governmental programmes. The "Idealised System of Values" (ISV) that the elite had proposed barely held up as designed, then, because pressure was brought to bear by all factors and from all directions. Whether or not these changes were significant in the short term or were good or bad for the population at large is another matter.

In general, this is the manner in which the ruling elite in social systems try to conserve their ideological schemes. Change becomes, then, a dialectic process deriving from a series of forces working for and against it. Although it is premature to go into detail at this stage, the difficulty lies in the definition of "significant change". Significant change is rare in social systems, at least over short periods of time. But as we know, the process of change is an unceasing and inherent aspect of such systems.

The model of social system presented here, simplified for the sake of comprehension, is rounded out with the description of its three basic dimensions: genetic, functional and behavioural as shown in Figure 1 (p.3) and Table 2 (p.10). 


\begin{tabular}{|c|c|c|}
\hline GENETIC & FUNCTIONAL & BEHAVIOURAL \\
\hline $\begin{array}{l}\text { 1. Structure-related (structural } \\
\text { factors) } \\
\text { 2. Shortage-related (people's } \\
\text { needs) } \\
\text { 3. Memory-related (historic } \\
\text { archives) }\end{array}$ & $\begin{array}{l}\text { 4. Conflict-related (axiological } \\
\text { disagreement) } \\
\text { 5. Hierarchy-related (socio- } \\
\text { political stratification) } \\
\text { 6. Teleology-related (pursuit of } \\
\text { objectives) } \\
\text { 7. Projection-related (ordering and } \\
\text { optimisation of Ends / Means). } \\
\text { Adapted system of values. } \\
\text { 8. Public transforming institutions. } \\
\text { 9. Private transforming } \\
\text { institutions. }\end{array}$ & $\begin{array}{l}\text { 10. Primary perception } \\
\text { (perception of primary objectives } \\
\text { outputs) } \\
\text { 11. Related to total primary } \\
\text { performance } \\
\text { 12. Total primary perception } \\
\text { (objective + subjective) } \\
\text { 13. Regulatory or control body } \\
\text { (objective and subjective } \\
\text { regulations) } \\
\text { 14. Related to final objective } \\
\text { outputs } \\
\text { 15. Related to final perception of } \\
\text { outputs. (subjective) } \\
\text { 16. Total final outputs. (objective } \\
+ \text { subjective) } \\
\text { 17. New inputs = total final } \\
\text { outputs. }\end{array}$ \\
\hline
\end{tabular}

Table 2: Fundamental dimensions of Social Systems

These seventeen dynamically interconnected dimensions are initially assumed to be valid for the analysis of any kind of society or institution organised around the achievement of its ends, regardless of the nature thereof or the ideology that inspires it. Nation states and tribes, multinational companies and small enterprises, families and groups of friends, schools, churches, etc. all seem to more or less fit the model described.

Finally, it must be admitted here that for the sake of clarity a highly simplified scheme is being used to represent complex socio-cultural systems. But the following must be understood: First, that each one of the dimensions presented may in turn be subdivided into any number of sub-dimensions, classes and types; second, that the arrows in the model proposed in Fig. 1 (p.3) refer only to the main direction of the general flow, but that given the complexity of the inter-relations among all the elements of the system, the arrows showing causal relationships, which are often mutual or recursive, may point in any imaginable direction. Modelling the social system calls for schematisation, but this by no means entails an oversimplification or loss of significance. It is a question, then, of stressing the model's transforming (or inputs or outputs), cybernetic (control of outputs), axiological (in the search for end-values) and sociological (values considered from, by, and for the people) orientations.

The systemic approach, like any theoretical orientation, leads us "despite ourselves" in a certain direction in our research. But we must try to see if this direction is appropriate and if it contributes something or improves upon other sociological approaches. According to A. Regnier, at least, "drawing up a model is to bring scientific discourse to a level of rigour where the formal logic of the predicates is valid". My argument, moreover, is not that it improves upon other theories, but rather that it integrates them; such integration consists of assuming and using them selectively and complementarily in accordance with the specific problems faced in the pursuit of the end in question. But what should perhaps be emphasised again is that the systemic approach constitutes a theory of relevance and error, as Churchman (1979) says; what this kind of globalising modelling intends to stress is precisely those relatively relevant or essential aspects that have been forgotten or ignored; the description of the model is both a description of the errors introduced in our "scientific" projection, and of the possible epistemological adulterations and subjective and ideological manipulations that may arise in each individual case. 
Once again, the importance of the four epistemological operations - Sociologisation, Systemisation of Needs, Systemisation of Resources and Teleologisation - must be emphasized. The core method and origin of the theorising process consists, then, of understanding the needs of the population and of taking the standpoint of the group as a whole, consisting of each and every one of the individuals that make it up as a starting point. In the proposed approach humans are at the hub of the system, are its raison d'etre, for whom the system should operate and for whom CHANGES should have a positive meaning. Moreover, although the group is no more than a pool of persons, it is necessary to take the group viewpoint, to empathically take the place of the man in the street to interpret "what the system needs". We shall see below that system needs thus interpreted call for other functions therein that are not political "action" or "decisions" (Easton), nor the division of powers (Almond) or even Parsons' famous AGIL scheme (Adaptation, Goals, Integration and Latent patterns), formulations which are inoperative not because they are too abstract, as is often said, but because they are sociologically out of focus. The sociological perspective calls for integration of the abstract (values) and the specific (needs just as people perceive them). It demands higher salaries and lower prices, good public service, good highways, security (law and order), freedom, an unpolluted natural environment, etc., and on the basis of these concrete needs to build a system of Values that are sufficiently abstract and operative to withstand axiological critique, as well as measurement and appraisal. Being overly abstract is as bad as being overly specific and, naturally, as bad as the failure to interpret needs and their corresponding functions in terms of self (Luhmann), i.e., as perceived by the system's own population.

A discussion of the explicit ends shown in Fig. 1 (p.3) is now in order and may be summarised as follows: 1) to measure the system's resources; 2) To determine its needs; 3 ) to determine who is to interpret what the system is to do; 4) to analyse the proposed system of values; 5) to analyse the implementation or transformation process, and 6) finally, to analyse the deviance between what the elite want, what the governments or bodies at their service achieve and what is finally perceived by the group as a whole. All of this seems to me to be by far the most interesting subject for debate in any social system, and the analysis and explanation thereof is what the axio-operational approach suggested here addresses. According to Churchman (1979), the systemic approach often generates questions that we would not otherwise have posed.

Finally, the ultimate consequences of this systemic modelling lie in proposing the end-values as the centre of epistemological attention. Indeed, nearly all the concepts drawn up under this approach must relate in some way to the values pursued and / or achieved by individuals or by the system as a whole. This is van Gigch's (1978, p. 150) line of reasoning when he maintains that values should be assigned to objectives, to alternatives, and to the outputs so as to be able to make rational decisions. Since the model, through the operation that we call "parsimonious selection", obliges us to focus on the most relevant and at the same time the most directly human aspects of the complex phenomenology, values become the essential language of the different system expressions. And according to van Gigch what is more important yet is that values, like any other attribute, may be measured; it is merely a question of defining the scale to be used.

It is the systematic use of what in the following point I will call "Reference Pattern of Values" that links these possible operational definitions of sociological concepts and calculations that in turn may make the axio-operational approach a more appropriate tool for social analysis.

\section{Needs, Values, Indicators}

Any social system inevitably revolves around two axial concepts. needs and values: Needs of the people and values for the people, both concepts referred to a theoretical list of common objectives that I will call the "Reference Pattern of Values" (RPV). The reciprocity of this pattern is such that if the needs of 
a given society can be expressed in a model of, for instance, 97 empirical indicators (such as the example I will be using), values must necessarily be expressed in terms of such 97 indicators; and if 22 indicators suffice to validly represent the needs of a second society, values must refer to these 22 indicators. Satisfaction depends on need and vice-versa, and the relationship between the two is shown in Fig. 2 .

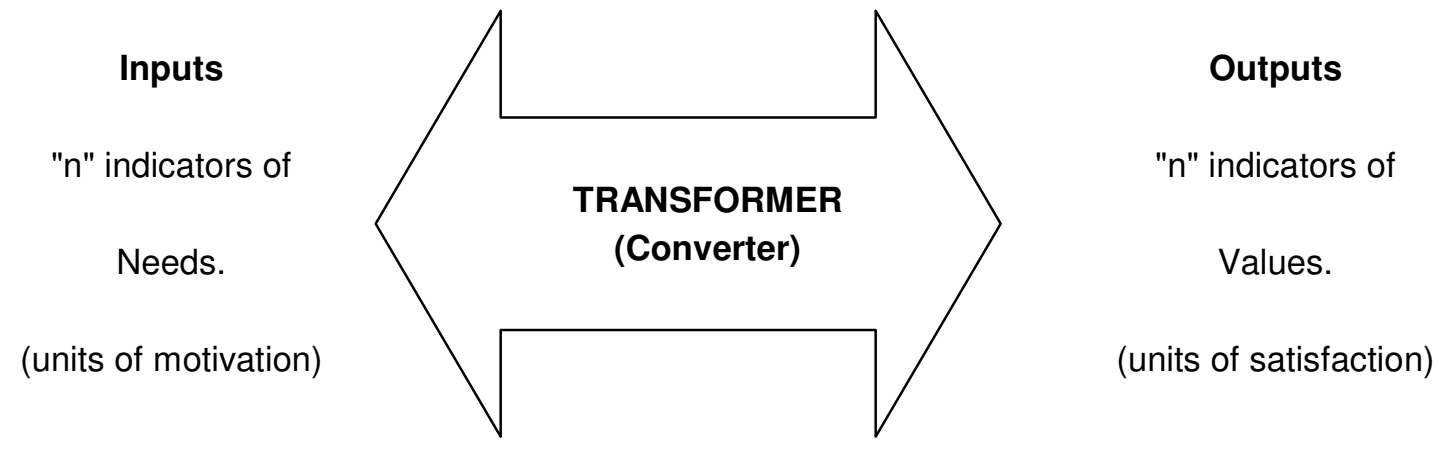

Fig. 2: "Transformation" of Needs into Values

All the transformation operation does (or should do) is to satisfy the people's needs, and the RPV is what acts as a theoretical-conceptual bridge to make needs and values, degrees of motivation and degrees of satisfaction, inputs and outputs, means and ends comparable. The RPV is designed, then, as we will see below, to attempt to measure - with an acceptable degree of accuracy - the overall efficiency of the system by comparing the two magnitudes.

The "Reference Pattern of Values" (RPV) therefore is a nominative relationship of end-values assumed to be desired, pursued or sought by the population at large. It is assumed to be valid to measure both the performance of social systems and important sociological concepts such as change, progress, social regression, socialisation, deviance and so on. It is postulated that most individuals, located in no-matterwhat space and time pursue these values from cradle to grave and the only thing that differentiates them is the emphasis or weight that each individual places on each value in a given circumstance. By "System of Values", in contrast, we mean the axiological configuration (or combination of the relative importance of the end-values) that each individual adopts as a living standard or pursues at any given time. The RPV is, then, a universal pattern while the system of values ranges so widely that there are probably as many such systems as individuals in society. The author (Parra-Luna, 1974, 1977, 1983) has been using a "Reference Pattern of Values" that seems to have been useful on several occasions. Such pattern is based on the adoption of nine essential needs, which the system attempts to satisfy via the achievement of nine quasi-universal functions and values, as shown in Table 3.

\begin{tabular}{|l|c|}
\hline \multicolumn{2}{|c|}{ THE REFERENCE PATTERN OF VALUES } \\
\hline HEALTH & $\mathrm{Y}_{1}$ \\
\hline WEALTH & $\mathrm{Y}_{2}$ \\
\hline SECURITY & $\mathrm{Y}_{3}$ \\
\hline KNOWLEDGE & $\mathrm{Y}_{4}$ \\
\hline FREEDOM & $\mathrm{Y}_{5}$ \\
\hline JUSTICE & $\mathrm{Y}_{6}$ \\
\hline ENVIRONMENTAL CONSERVATION & $\mathrm{Y}_{7}$ \\
\hline QUALITY OF ACTIVITIES & $\mathrm{Y}_{8}$ \\
\hline PRESTIGE & $\mathrm{Y}_{9}$ \\
\hline
\end{tabular}

Table 3: The reference pattern of values. 
From Table 3 (p.12), are through the standardization of dates (Parra-Luna, 2001), it can be worked out

$$
\mathrm{N}=\sum_{\mathrm{l}=1}^{9} \mathrm{~N}_{\mathrm{i}} / 9
$$

As the average level of the needs of the system in the same way.

$$
Y=\sum_{l=1}^{9} Y_{i} / 9
$$

"Y" is the average level of outputs.

The number "9" is logically the number of complex values in the expression, but if a longer number of empirical indicators ( $n$ ) are used, the formula should use "n" instead of 9 . For instance, if we use the 84 indicators suggested for the nation state in Table 4 (p.17-22), then, the expressions should be:

$$
\begin{aligned}
& N=\sum_{\mathrm{l}=1}^{84} \mathrm{~N}_{\mathrm{i}} / 84 \\
& \mathrm{Y}=\sum^{84} \mathrm{Y}_{\mathrm{i}} / 84
\end{aligned}
$$$$
\mathrm{l}=1
$$

The order in which the needs and values are shown has no particular significance. Nevertheless, health and economic needs (which correspond more or less to what Maslow called physiological needs) are generally considered to have priority over protection against contingencies. The latter, in turn, is usually felt to be higher on the list of priorities than knowledge and naturally than other more political needs such as justice (social) or freedom. Lowest on the list would be power, harmony with nature, self-fulfilment and power and prestige. 
This nine-value model is based on two premises mentioned above but which should be stressed here.

1. In the complex world of needs and culture, values can be classified under two major categories: variable and constant. The former are those that are characteristic of each specific culture, which will be considered secondary (dress, greeting, eating, celebrating important events, etc.). The latter are values that are common to all societies and the ones on which we have focused to establish the RPV (health, safety, justice, etc.). The former are culture-specific, the latter general and universal.

2. The degree of specificity and abstraction of the model must strike a balance between a small number of highly abstract system functions (as in Parsons) and a large number of specific indicators. Actually, we find that we must choose between a single value, that consists of achieving general well-being, and among all the aspects or sub-values that may define it operationally. Well-being seems to be the goal on which we all target and think that we can reach through multiple factors that may be represented by the nine values proposed in the model and the hundreds or even thousands of indicators that make them operative. But while a single concept of well-being would not be useful because it would entail concentrating information too highly, it would be equally unwise to use so many indicators that it becomes unmanageable. The Reference Pattern of Values to be used must, then, be a model comprising not more than ten essential values, to strike a happy medium both allowing for an understanding of the theoretically important dimensions of the system and providing a way of formulating them in a structure that is clear and meaningful to the population. It is a matter of balance between maximum specificity and minimum detail to ensure manageability, but also and above all, of adopting a sociological approach, that is to say, of ensuring that the meaning of RPV is directly perceived by and for the population.

Before going into a list of the indicators under which the nine values in Table 3 (p.12) would operate, certain comments about the specific indicators to be proposed are in order. First of all, as I mentioned above, the indicators are designed for application to a national system. This entails the advantage mutatis mutandis that it is easy to move from these complex social systems to simpler ones. The number of indicators proposed to define a given value has no bearing on the relative importance of the value; a value represented by only a few highly concentrated indicators may be considered to be more important than others with a larger number of indicators. The system of indicators is not limited to using existing information, but in fact empowers it by pointing out the need for additional information. Thus, for example, routine statistics on the "number of working days lost due to accidents" are not always readily available, but they would be very useful, and this suggests a possible indicator. Indicators are characterised by being as direct as possible, and therefore highly concentrated. When an attempt is made, for example, to see how well the value "(Social) Justice" is working, we will not review the personal distribution of economic income, which is the usual procedure, but rather certain special mobility indicators that consider not only the distribution of such income, but also of other - cultural, political, social etc. - "incomes". If these mobility indices show that the situation is satisfactory, it must of course be concluded that economic income is appropriately distributed. The indicators proposed always intend to be the shortest route to the information, focusing more on ends than on means. Finally, the indicators are as unambiguous as possible; in other words, they represent values desired by a majority of the people. Thus, for instance, a religiosity index is not included because there is no clear consensus about whether being religious is "good" or "bad" as there is, for example, about being healthy or ill. There are, of course, some indicators on the suggested list that are somewhat ambiguous in this regard, but they have been kept to a minimum. Moreover, certain areas of concern may be missing; needless to say, this is an open and dynamic list that must be adapted to cover the information most suitable to each kind of system reviewed or specific research study. The list presented here intends merely to cover a number of generally applicable essential indicators. 


\section{The indicators}

\subsection{Health}

It is assumed that one of the fundamental objectives pursued by most individuals and peoples is to live as long as possible in the best possible health or physical and mental condition. With respect to the indicators, it is suggested that this value be quantified using the indicators traditionally employed by the World Health Organisation to define the state of health of the people in each nation.

\subsection{Material wealth}

It is assumed that most individuals and peoples wish to live as comfortably as possible. Table 4 (p.17) shows the indicators that refer in general to material standard of living, under two general headings, "standard of living" and "economic security". The indicators intend to focus on the actual standard of living of the population as a whole. The index on savings, not at all easy to obtain in full, provides information both on economic power and on the degree of future security and as such should be interpreted.

\subsection{Security and law and order}

It is likewise assumed that individuals prefer, in general, to live peacefully and orderly in accordance with known rules and where contingencies and the need to rise to new circumstances do not entail too much discord or call for making inordinate efforts to adapt to them. Table 4 (p.18) includes two dimensions in an attempt to measure what we have called public and operational safety, and assuming that the indicators suggested validly represent what is usually understood to be safety in a modern nation state.

\subsection{Knowledge}

It is assumed that most individuals and peoples are curious to know about their surroundings. Table 4 (p.18) attempts to quantify the value "Knowledge" in three dimensions: "Educational Level", "Reading" and "Research". Other indicators that have not been included, such as intermediate educational levels, the domestic consumption of paper for printing (deducting exports) or the number of patents registered, may also be used.

\subsection{Freedom}

The following working hypothesis is assumed: freedom (political, of expression, of movement, etc.) is desired and pursued by most individuals regardless of the kind of social organisation they live in.

\subsection{Justice}

It is likewise assumed that equality among human beings, regardless of race, religion, ideology, sex, etc., is a generally accepted principle among civilized peoples.

Table 4 (p.20) shows how well the "total national pie", i.e., economic, cultural, functional, etc., is distributed among the individual members of the social system. The 21 indicators used are somewhat different than the indices most commonly used to measure distribution of wealth. However, as mentioned above, the distribution of economic wealth is implicit in these indicators. The result of this set of indicators would undoubtedly be quite surprising, especially if actual percentages are compared. Thus, for example, it is maintained that if 51 per cent of a population are women, ideally (i.e., the target) 51 per cent of the executives running the economic, political, religious, etc. sub-systems should be women. If this is not the case, the implications are, aside from the effect of certain biological determinants in women's professional 
activities, that for whatever initial and historic reasons, the operation of the system is "structured" to keep women's influence, or at least their direct influence, to a minimum. Deeply entrenched educational principles and unconsciously sexist attitudes lead to situations in which there are, for instance, no female generals, bishops or union leaders in certain social systems. The general discriminatory principles that are at the root of this system conduct are likewise present in the case of other groups that are discriminated against, such as workers or underprivileged class children, blacks, etc. The ideal, of course, would be for all of the indices comparing $\%$ of positions held to $\%$ of population be as close as possible to one. Any deviation from that result would in principle mean undeniable de facto discrimination. Table 4 (p.20), then, provides a very general summary of the actual level of "equal opportunities" existing in the society under study.

\subsection{Environmental conservation}

It is further postulated that one of the urgent needs of modern society and one of the targets of economically developed countries is conservation of the environment, to counter the detrimental effects of such development. Table 3 (p.12) lists the indicators suggested for "Environmental Conservation". Sight should not be lost of the fact that most of the information required for this values either does not exist or is still being compiled, so institutional efforts are called for in this regard.

\subsection{Quality of activities}

It is assumed that all human beings should develop their full potential, which development should take place in all dimensions and aspects of life, from work to relaxation, from suffering to pleasure, from birth to death. Table 4 (p.21) shows the indicators that represent this value called "Quality of Activities" which are an attempt to measure in some way the extent to which human beings participate, create, and reach selffulfilment and self-development via the enhancement of their human capacities.

\subsection{Prestige}

Finally, another working hypothesis on which the "Reference Pattern of Values" is based assumes that individuals need to give, do something valuable for others, and to seek love, admiration and respect. Table 4 ( $p .22$ ) shows the indicators for prestige, here understood in the international sense, since initially it is referred to the nation state. Application to other systems will of course call for the adaptation of such indicators. 


\begin{tabular}{|c|c|c|}
\hline \multicolumn{3}{|c|}{ INDICATORS } \\
\hline NATION STATE & ENTERPRISE & UNIVERSITY \\
\hline $\begin{array}{l}\text { HEALTH } \\
\text { Life expectancy } \\
\text { - Life expectancy of one-year-old. } \\
\text { (females) } \\
\text { - Proportional mortality rate at the } \\
\text { age of } 50 . \\
\text { - Infant mortality at the age of } 1 . \\
\text { (inverse index) } \\
\text { Quality of life } \\
\text { - Days not worked due to illness } \\
\text { or accident. (inverse index) } \\
\text { Means dimension } \\
\text { - Medical or paramedical } \\
\text { staff } / 10.000 \text { inhab. } \\
\text { - Hospital beds/10.000inhab. }\end{array}$ & $\begin{array}{l}\text { HEALTH } \\
\text { - Days not worked due to illness. } \\
\text { (inverse index) } \\
\text { - Day lost due to accident / total } \\
\text { numbers of employees. }\end{array}$ & $\begin{array}{l}\text { HEALTH } \\
\text { - Lost days due to illness. } \\
\text { (inverse index) }\end{array}$ \\
\hline $\begin{array}{l}\text { MATERIAL WEALTH } \\
\text { Standard of living } \\
\text { - Homes with no running water. } \\
\text { (inverse index) } \\
\text { - Homes without electricity. } \\
\text { (inverse index) } \\
\text { - } \text { M }^{2} \text { of housing and land per } \\
\text { capita. } \\
\text { - \% of GNP spent on tourism } \\
\text { abroad. } \\
\text { - Number of telephones/1.000 } \\
\text { homes. } \\
\text { - Per capita Gross National } \\
\text { Product. } \\
\text { - Number of cars } / 1.000 \\
\text { inhabitants. } \\
\text { Level of economic security } \\
\text { - Savings. }\end{array}$ & $\begin{array}{l}\text { MATERIAL WEALTH } \\
\text { - Turnover (millions of pesetas). } \\
\text { - Productivity: units of } \\
\text { outputs/total number of } \\
\text { employees. } \\
\text { - Overall wages per } \\
\text { employee/wages of employee in } \\
\text { sector. } \\
\text { - Dividends paid out/standard } \\
\text { dividends in sector. } \\
\text { - Return on capital invested. }\end{array}$ & $\begin{array}{l}\text { MATERIAL WEALTH } \\
\text { - (Total budget - total income } \\
\text { from students)/Total budget. } \\
\text { - Average general salary. } \\
\text { - \% graduates working during the } \\
\text { first year. } \\
\text { - Percentage of students with } \\
\text { fellowships. } \\
\text { - Average total cost for } \\
\text { students/average total cost for } \\
\text { students in competitive } \\
\text { universities. }\end{array}$ \\
\hline
\end{tabular}




\begin{tabular}{|c|c|c|}
\hline \multicolumn{3}{|c|}{ INDICATORS } \\
\hline NATION STATE & ENTERPRISE & UNIVERSITY \\
\hline $\begin{array}{l}\text { SECURITY (LAW AND ORDER) } \\
\text { Public safety } \\
\text { Domestic } \\
\text { - Crime rate. (inverse index) } \\
\text { - Number of death due to political } \\
\text { unrest or revolutionary } \\
\text { processes. (inverse index) } \\
\text { - Total number of demonstrations } \\
\text { (authorized + non authorized). } \\
\text { (inverse index) } \\
\text { - Number and power of nuclear } \\
\text { power plants for peaceful } \\
\text { purposes. (inverse index) } \\
\text { - Foreign military bases. (inverse } \\
\text { index) } \\
\text { - Number of coups d'etat. } \\
\text { (inverse index) } \\
\text { - Number of (proven) attempted } \\
\text { an unsuccessful coup d'etat. } \\
\text { (inverse index) } \\
\text { Foreign } \\
\text { - Number of deaths due to } \\
\text { conflicts abroad. (average } \\
\text { index) } \\
\text { - Military power. } \\
\text { - Nuclear military risk. (inverse } \\
\text { index) } \\
\text { Operational } \\
\text { - Days not worked due to labour } \\
\text { conflicts. (inverse index) } \\
\text { etc.). (inverse index) } \\
\text { - Number of accidents (job, traffic, }\end{array}$ & $\begin{array}{l}\text { SECURITY } \\
\text { - Functional security. (inverse } \\
\text { index) } \\
\text { - Number of employees } \\
\text { injured/total number of } \\
\text { employees. } \\
\text { - Number of functional } \\
\text { incidents/total number of } \\
\text { employees. } \\
\text { - Working days lost due to strikes } \\
\text { or disputes/total number of } \\
\text { employees. } \\
\text { - Staff of subcontracted } \\
\text { companies/total number of } \\
\text { employees. } \\
\text { - Level of customer satisfaction. } \\
\text { - Financial security. } \\
\text { - Monthly liquidity. } \\
\text { - Guarantee index. } \\
\text { - Sinking fund/investment } \\
\text { necessary. } \\
\text { - Annual reserve } \\
\text { endowment/turnover. } \\
\text { - Accumulated reserves/equity. }\end{array}$ & $\begin{array}{l}\text { SECURITY } \\
\text { - Lost days due to professor's } \\
\text { strikes. (inverse index) } \\
\text { - Lost days due to student's } \\
\text { strikes. (inverse index) } \\
\text { - Number of incidents. (inverse } \\
\text { index) }\end{array}$ \\
\hline $\begin{array}{l}\text { KNOWLEDGE } \\
\text { Educational level } \\
\text { - Illiteracy rate. (inverse index) } \\
\text { - Children not enrolled in schools. } \\
\text { (inverse index) } \\
\text { - \% of university graduates. } \\
\text { Reading level } \\
\text { - Press. Index } \\
\text { - Number of books per home. }\end{array}$ & $\begin{array}{l}\text { KNOWLEDGE } \\
\text { - \% of university graduates. } \\
\text { - Royalties trade balance. } \\
\text { - \% of income consecrated to } \\
\text { research. } \\
\text { - Training: employers } \\
\text { engaged/total numbers of } \\
\text { employees. } \\
\text { - Average training level of staff. } \\
\text { - Participants in training }\end{array}$ & $\begin{array}{l}\text { KNOWLEDGE } \\
\text { - Number of articles } \\
\text { published/number of professors. } \\
\text { - Income due to research/number } \\
\text { of professors. } \\
\text { - Number of books } \\
\text { published/number of professor. } \\
\text { - The average of marks achieved } \\
\text { during the most recent nation- } \\
\text { wide research assessment }\end{array}$ \\
\hline
\end{tabular}




\begin{tabular}{|c|c|c|}
\hline \multicolumn{3}{|c|}{ INDICATORS } \\
\hline NATION STATE & ENTERPRISE & UNIVERSITY \\
\hline $\begin{array}{l}\text { Research } \\
\text { - Royalties trade balance. Index } \\
\text { - \% GNP devoted to research. }\end{array}$ & $\begin{array}{l}\text { courses/total number of } \\
\text { employees. } \\
\text { - Purchase and rate index of } \\
\text { patents and royalties. } \\
\text { - Research aid/total expenditure. } \\
\text { - Suggestion accepted/total } \\
\text { number of employees. } \\
\text { - Intellectual capital/total number } \\
\text { of employees. }\end{array}$ & $\begin{array}{l}\text { exercise. } \\
\text { - Postgraduate research } \\
\text { students/postgraduate taught } \\
\text { students. } \\
\text { - Income for research/total } \\
\text { budget. } \\
\text { - Number of Ph.D. for } \\
\text { year/number of students. }\end{array}$ \\
\hline $\begin{array}{l}\text { FREEDOM } \\
\text { Political } \\
\text { - Number of political prisoners (or } \\
\text { persons shut away in psychiatric } \\
\text { hospitals, deported, etc.). } \\
\text { (inverse index) } \\
\text { - Rate of authorized/non- } \\
\text { authorized demonstrations. } \\
\text { - Number of free elections, } \\
\text { referendums, etc. per year. } \\
\text { - Freedom of the press and } \\
\text { editorial freedom. } \\
\text { - Mentions in Amnesty } \\
\text { International reports. (inverse } \\
\text { index). } \\
\text { Social } \\
\text { - Foreign migration rate. } \\
\text { - Domestic migration rate. } \\
\text { Religious } \\
\text { - Separation of Church and State. } \\
\text { - Freedom of worship. } \\
\text { - Freedom of propaganda. }\end{array}$ & $\begin{array}{l}\text { FREEDOM } \\
\text { - General information meetings. } \\
\text { - Departmental information } \\
\text { meetings. } \\
\text { - Hours of trade union activities } \\
\text { during working hours/total } \\
\text { number of employees. } \\
\text { - Level of unionisation: unionised } \\
\text { employers/total number of } \\
\text { employees. }\end{array}$ & $\begin{array}{l}\text { FREEDOM } \\
\text { - Freedom to choose maters. } \\
\text { - Freedom to choose professors. } \\
\text { - Number of students belonging } \\
\text { to free associations. }\end{array}$ \\
\hline
\end{tabular}




\begin{tabular}{|c|c|c|}
\hline \multicolumn{3}{|c|}{ INDICATORS } \\
\hline NATION STATE & ENTERPRISE & UNIVERSITY \\
\hline $\begin{array}{l}\text { JUSTICE } \\
\text { By gender } \\
\text { - Percentage of women in } \\
\text { Parliament and the } \\
\text { Government. } \\
\text { - Percentage of female executive } \\
\text { presidents of the } 1.000 \text { largest } \\
\text { (public or private) companies in } \\
\text { the country. } \\
\text { - Percentage of women generals } \\
\text { in the armed forces. } \\
\text { - Percentage of women editors- } \\
\text { in-chief of the } 200 \text { largest } \\
\text { newspapers in the country. } \\
\text { - Number of women bishops. } \\
\text { By race } \\
\text { - Percentage of blacks, gypsies } \\
\text { or other marginal minority in the } \\
\text { Parliament and Government. } \\
\text { - Percentage of blacks, gypsies } \\
\text { or other marginal minority that } \\
\text { are bishops. } \\
\text { By social background } \\
\text { - Percentage of members of } \\
\text { Parliament or the Government } \\
\text { who were born in the working } \\
\text { class. } \\
\text { - Percentage of bishops who } \\
\text { were born in the working class. }\end{array}$ & $\begin{array}{l}\text { JUSTICE } \\
\text { - Salary scale: lowest/highest } \\
\text { wages. } \\
\text { - Average women's } \\
\text { wages/average men's wages for } \\
\text { equal works. } \\
\text { - Average women's } \\
\text { wages/average men's wages. } \\
\text { - Objective recruitment/total } \\
\text { recruitment. } \\
\text { - Objective promotions/ total } \\
\text { promotions. } \\
\text { - Share in profits: profits } \\
\text { distributed to personal/total } \\
\text { profits. } \\
\text { - Staff entitled to corporate } \\
\text { profits/total number of } \\
\text { employees. } \\
\text { - Staff entitled to stocks } \\
\text { options/total number of } \\
\text { employees. } \\
\text { - Staff entitle to works } \\
\text { bonuses/total number of } \\
\text { employees. }\end{array}$ & $\begin{array}{l}\text { JUSTICE } \\
\text { - Student participation in } \\
\text { examinations. }\end{array}$ \\
\hline $\begin{array}{l}\text { ENVIRONMENTAL } \\
\text { CONSERVATION } \\
\text { Fauna } \\
\text { - Quantity - index. } \\
\text { - Diversity - index. } \\
\text { Flora } \\
\text { - Quantity - index. } \\
\text { - Hectares lost to fire. (inverse } \\
\text { index) } \\
\text { - Diversity - index. } \\
\text { - Atmospheric pollution rate. } \\
\text { (inverse index) } \\
\text { - River pollution rate. (inverse }\end{array}$ & $\begin{array}{l}\text { ENVIRONMENTAL } \\
\text { CONSERVATION } \\
\text { - Percentage of park areas. } \\
\text { - Environmental measures in } \\
\text { favour of the personnel, if } \\
\text { appropriate. } \\
\text { - Environmental measures in } \\
\text { favour of society, if appropriate. }\end{array}$ & $\begin{array}{l}\text { ENVIRONMENTAL } \\
\text { CONSERVATION } \\
\text { - Percentage of park areas in the } \\
\text { campus. }\end{array}$ \\
\hline
\end{tabular}




\begin{tabular}{|c|c|c|}
\hline \multicolumn{3}{|c|}{ INDICATORS } \\
\hline NATION STATE & ENTERPRISE & UNIVERSITY \\
\hline $\begin{array}{l}\text { index) } \\
\text { - Sea pollution rate. (inverse } \\
\text { index) } \\
\text { - Percentage of park areas in } \\
\text { cities > } 100.000 \text { inhabitants }\end{array}$ & & \\
\hline $\begin{array}{l}\text { QUALITY OF ACTIVITIES } \\
\text { Unemployment dimension } \\
\text { - Unemployment rate. (inverse } \\
\text { index) } \\
\text { Participation dimension (worker } \\
\text { management and self- } \\
\text { employment) } \\
\text { Rate of worker participation } \\
\text { - Self-employed workers. } \\
\text { - Workers in worker-managed } \\
\text { firms. } \\
\text { - Workers in cooperatives. } \\
\text { - University professors and public } \\
\text { school teachers. } \\
\text { - Other self-employed } \\
\text { professionals. } \\
\text { - Participation in public life. } \\
\text { - Time devoted to political } \\
\text { militancy. } \\
\text { - Time devoted to labour union } \\
\text { militancy. } \\
\text { - Time devoted to militancy in } \\
\text { citizens' groups. } \\
\text { - Leisure time and artistic work } \\
\text { dimension } \\
\text { - Hours worked per week. } \\
\text { (inverse index) } \\
\text { - Artistic production. } \\
\text { - Number of paintings exhibited. } \\
\text { - Number of recordings. } \\
\text { - Number of sculptures exhibited. } \\
\text { produced. }\end{array}$ & $\begin{array}{l}\text { QUALITY OF ACTIVITIES } \\
\text { Suggestion received value } \\
\text { - Suggestion received/total } \\
\text { number of employees. } \\
\text { - Workers involved in quality/total } \\
\text { number of employees. } \\
\text { - Workers in boards of managing } \\
\text { directors/member of managing } \\
\text { directors. } \\
\text { - Workers in boards of } \\
\text { administration/members of } \\
\text { boards of administration. } \\
\text { - Social and working atmosphere } \\
\text { barometers. } \\
\text { - Percentage of temporary staff. } \\
\text { - Average duration of temporary } \\
\text { contracts. } \\
\text { - Personnel with flexible working } \\
\text { hours/total number of } \\
\text { employees. } \\
\text { - Personnel working at home/total } \\
\text { number of employees. } \\
\text { - Overtime/total number of } \\
\text { employees. } \\
\text { - Emotional capital. }\end{array}$ & $\begin{array}{l}\text { QUALITY OF ACTIVITIES } \\
\text { - Number of professors/number of } \\
\text { students. } \\
\text { - Books on library/number of } \\
\text { students. } \\
\text { - Computers with free internet } \\
\text { access/number of students. } \\
\text { - Infomatization index. } \\
\text { - Tutorials/number of students. } \\
\text { - Index of students participation in } \\
\text { university government. } \\
\text { - Index of artistic activities. } \\
\text { - Computer expense/total } \\
\text { expenses. } \\
\text { - Library expense/total expense. } \\
\text { - Percentage of full time. } \\
\text { - Total capacity of } \\
\text { laboratories/number of students. } \\
\text { - Total capacity in library/number } \\
\text { of students. } \\
\text { - Total number of computers for } \\
\text { students/number of students. }\end{array}$ \\
\hline
\end{tabular}




\begin{tabular}{|c|c|c|}
\hline \multicolumn{3}{|c|}{ INDICATORS } \\
\hline NATION STATE & ENTERPRISE & UNIVERSITY \\
\hline $\begin{array}{l}\text { PRESTIGE } \\
\text { - Percentage of GNP devoted to } \\
\text { donations abroad. } \\
\text { - Number of international } \\
\text { organisations with headquarters } \\
\text { in the country. } \\
\text { - Rate of foreign immigration. } \\
\text { - Number of foreign military } \\
\text { stationed in national territory. } \\
\text { (inverse index) } \\
\text { - Population growth rate. } \\
\text { - Rate of success in international } \\
\text { - Rports competition. } \\
\text { - Rate of success in international } \\
\text { art shows. }\end{array}$ & $\begin{array}{l}\text { PRESTIGE } \\
\text { - Level of customer satisfaction. } \\
\text { - Internal spending/total } \\
\text { expenditure. } \\
\text { - External social spending/total } \\
\text { expenditure. } \\
\text { - Dishonoured bills/turnover. } \\
\text { - Corporate image. } \\
\text { Power } \\
\text { - Market share. } \\
\text { - Number of employees. } \\
\text { - Strategic alliances, total market } \\
\text { share. } \\
\text { - Total personnel in affiliated } \\
\text { companies. }\end{array}$ & $\begin{array}{l}\text { PRESTIGE } \\
\text { - Prizes received by professors. } \\
\text { - Honoris cause received by } \\
\text { professors. } \\
\text { - Average position in } \\
\text { classification of universities. } \\
\text { - Applications to places: the total } \\
\text { number of applications to } \\
\text { degree courses against the total } \\
\text { applicants accepted. } \\
\text { - Income from industry/total } \\
\text { income. } \\
\text { - Student's qualification required } \\
\text { for entering at the University. }\end{array}$ \\
\hline
\end{tabular}

Table 4: Indicators for Nation states, enterprises and universities.

This, then, is an initial list of indicators that are intended to quantify the proposed "Reference Pattern of Values" in an attempt to reflect both the needs of any socio-political system and therefore what should be done, regardless of the emphasis placed on each specific value, dimension or indicator. The pattern, merely a nominal model of values to be pursued by any society, intends to be a unique tool, i.e., to serve as a common scheme for the analysis and comparison of societies. What will differ is the "Systems of Values" arising from the different emphasis or possibilities of practical implementation of the values, and the indicators that represent them, which depend on the dimension and type of social system.

To make the distinction between "Reference Pattern of Values" (RPV) and "System of Values" perfectly clear, Figure 3 stresses the nominal nature of the former and the gradual nature of the latter.

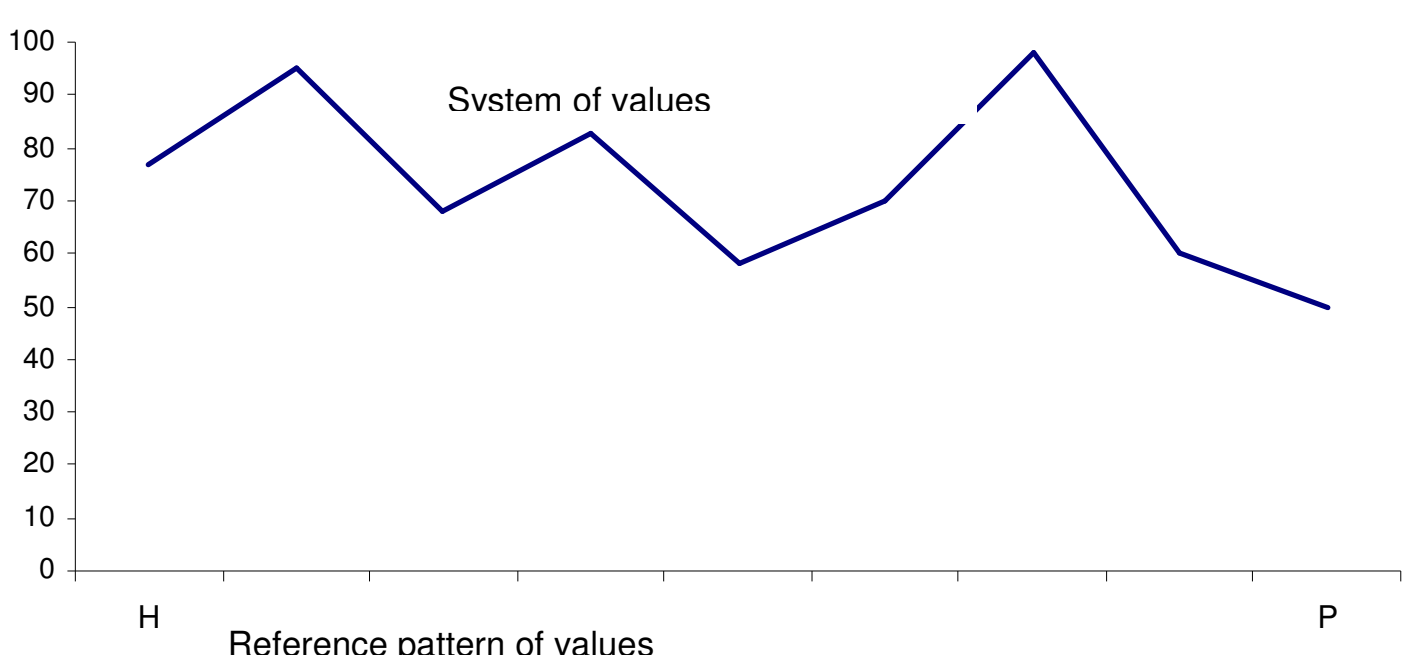

Figure 3: Difference between "Reference Pattern of Values" (RPV) and "System of Values" 
The roster of needs is, then, one of the highlights of the theory of social systems, the core around which the operational theory proposed revolves. Given the central role that RPV plays in this theory, we feel that a more complete formulation of the pattern is one of the most pressing needs in current systems theory. The present discussion is simply a first step taken in the hope that work will continue to be undertaken in this important field by others, better qualified or more fortunate.

\section{Conclusion}

I have decided not to go into an extensive discussion of why each indicator was included in the above nine tables so as not to make this paper excessively long. I trust that for the time being behind the assignment of each indicator to its respective value is more or less transparent.

Having introduced RPV as the general measurement standard, the first methodological concern that arises before proceeding to quantify the model involves homogenization or standardization of the indicators to make their results directly comparable, which is not difficult to perform in any of its varieties. In short, the values and indicators to be used as outputs should meet the three basic requirements suggested in Table 1 (p.2): a) they must be defined to be good (this can be done by a weighted sample of experts); b) they must be desired by the population at large; and c) they must be obtainable onerously or must be of an "acquired" rather than an "ascribed" nature. Goodness, desirability and onerosity are then, the three basic traits that a value must have to be included in the "Reference Pattern of Values". Through these requirements and the standardization of the empirical indicators used, it will be possible, then, to define operationally such concepts like change, progress, social development, social regression and many others. This endeavour, within the research process on the Axiological Systems Theory program, has been suggested in Parra-Luna (2001/02).

\section{References}

Buchanan, B. (1998). Information Requirements for a Viable Society. Paper delivered al the XIV World Congress of Sociology, Montreal, July.

Buchanan, B. (2000). The Role of Values in Measuring the Performance of Social Systems. In Parrra-Luna (ed.). The Performance of Social Systems: Perspectives and Problems. Kluwer/Plenum, N.Y.

Churchman, W. (1979). The System Approach and its Enemies. Eng. Cliffs. N.J.

Deutsch, K. W. (1974). "Politics and Government: How people decide their fate". Boston, Hougthon Mifflin Co.

Easton, D. (1965). Esquema para el analisis politico. Amorrortu, Buenos Aires.

Flood, R.L. and Jackson, M. (eds.) (1991). Critical Systems Thinking: Directed Readings. Wiley. New York.

Gigch van, J.P. (1978). Applied General Systems Theory. Harper \& Row, Pub. N.Y.

Hall. B. P. (1994). Values Shift. Twin Light Pub., Rockport, M.A.

Hall, Martin-Lewis, W. (1999). Systems Thinking and Human Values: Towards Understanding the Chaos in Organizations. Paper delivered at the XIV World Congress of Sociology, Montreal, July.

Parra-Luna, F. (1974). Towards Comparing National Social Performances. Univ. Lausanne.

Parra-Luna, F. (1977). Las Organizaciones y sus sistemas de valores. Boletin de Doc. Confed. Esp. Cajas de Ahorro, Vol. IX, Fasc. 3- Julio- Sepbre.

Parra-Luna, F. (1983). Elementos para una teoria formal del sistema social. Univ. Complutense, Madrid.

Parra-Luna, F. (2001/02). An Axiological Systems Theory: Some basic hypotheses in Systems Research and Behavioural Sciences. (Provisionally scheduled for 18-6, 2001 or 2002).

Ulrich, W. (1991). Critical heuristics of social systems design, and systems thinking, systems practice, and practical philosophy: A program of research. In Flood and Jackson (1991). 